\title{
Why Do Hedgers Trade So Much?*
}

\author{
Ing-Haw Cheng ${ }^{\dagger}$ and Wei Xiong ${ }^{\S}$
}

January 2014

\begin{abstract}
Futures positions of commercial hedgers in wheat, corn, soybeans and cotton fluctuate much more than expected output. Hedgers' short positions are positively correlated with price changes. Together, these observations raise doubt about the common practice of categorically classifying trading by hedgers as hedging while trading by speculators as speculation, as hedgers frequently change their futures positions over time for reasons unrelated to output fluctuations, arguably a form of speculation.
\end{abstract}

* We are grateful to Jose Scheinkman and Glen Weyl for helpful comments.

${ }^{\dagger}$ Tuck School of Business, Dartmouth College, e-mail: ing-haw.cheng@tuck.dartmouth.edu.

$\S$ Department of Economics and Bendheim Center for Finance, Princeton University, e-mail: wxiong@ princeton.edu. 
Financial innovations such as derivatives facilitate not only risk sharing and price discovery, but critics also argue that they lead to reckless speculation which amplifies price volatility and hinders efficient risk sharing (Posner and Weyl, 2013). This concern has led to a debate on the regulation of financial innovation and trading of financial derivatives, and warrants a benefit-cost analysis of financial regulation. In this debate, as well as in other broad contexts of analyzing risk sharing and trading in financial markets, it is common to separate two groups of traders - one group of traders with established commercial interests, labeled hedgers, and another group of financial traders, labeled speculators.

Perhaps due to this distinction, the debate heavily focuses on examining the behavior and impact of speculators, with little attention on how hedgers trade in practice. Policy prescriptions often focus on the behavior of the speculator group while exempting the hedger group. ${ }^{1}$ Is this categorical treatment justified? Do hedgers trade just to hedge risk in their commercial business? Or might there be other factors driving their trading? In this paper, we systematically examine how hedgers trade in the futures markets of a set of agricultural commodities: wheat, corn, soybeans and cotton.

Commodity futures markets offer a nice setting to examine the distinction between hedgers and speculators. Futures contracts on agricultural commodities were early financial innovations that have a long history of serving farmers and commodity producers to hedge the commodity price risk they face. The long-standing hedging pressure theory of Keynes (1923) emphasizes the imbalance between the need of commodity producers to short sell commodity futures contracts and the lack of interest from speculators to take the long side as a key determinant of commodity futures prices. Through the financialization of commodity futures markets in the last decade, commodity futures became a popular asset class for portfolio investors and have attracted large inflows of investment capital in the magnitude of hundreds of billions dollars to the long side. The large capital inflows have led to a heated debate on the role of speculation in commodity futures markets, particularly concerned with financial traders destabilizing commodity prices. ${ }^{2}$ While this debate focuses on financial traders, more attention on how hedgers trade is also warranted.

\footnotetext{
${ }^{1}$ For example, the Commodity Futures Trading Commission (CFTC) has considered position limits in futures markets, from which so-called "bona fide hedgers" may obtain exemptions.

${ }^{2}$ See Cheng and Xiong (2013) for a review of this debate.
} 
The U.S. Commodity Futures Trading Commission (CFTC) publishes data on the aggregate position levels in its Commitments of Traders (COT) reports. By regulation, clearing houses of commodity futures markets report the end-of-day positions of traders with positions larger than certain reporting thresholds to the CFTC, which classifies each reportable trader into several categories, and reports aggregated weekly positions at the group level to the public. Individual traders are distinguished based on whether they have commercial interests in each commodity (CFTC, 2013). For the bulk of our analysis, we focus on the behavior of Producer/Merchant/Processor/User positions reported in the CFTC's Disaggregated COT report, and consider how these commercial hedgers trade.

Our analysis examines whether commercial hedgers' trading patterns are consistent with a simple benchmark notion of hedging in which risk-averse commercial hedgers take short positions in futures to mitigate their endowed commodity price and output risk. We proceed in two steps.

First, we compare the intensity of hedgers' trading with the uncertainty in the aggregate output of each commodity. Intuitively, in the absence of output uncertainty, a fixed hedging position equal to the size of the output would perfectly hedge the price risk faced by hedgers. In the presence of output uncertainty, Rolfo (1980) and Hirshleifer (1991) develop theoretical models to show that hedgers tend to under-hedge as output is negatively correlated with price and that their hedging position would fluctuate with expected output. Our empirical analysis shows that although hedgers' futures positions are much smaller than output, the volatility of their positions is much higher than the output volatility measured by either the year-to-year output fluctuation or month-to-month fluctuation of professional output forecasts. Furthermore, although output uncertainty declines over the harvest season, hedgers' trading volatility remains stable throughout the year.

In the second step of our analysis, we examine what else might explain the volatility of hedgers' futures positions. We find that hedgers respond strongly to price changes. They short more futures contracts when the futures price rises, and reduce their short position as the futures price falls. ${ }^{3}$ It is difficult to reconcile such trading behavior purely based on hedging strategies of risk-averse hedgers seeking to hedge price and output uncertainty. For example, if prices rise in response to a

\footnotetext{
${ }^{3}$ In a related paper, Kang, Rouwenhorst, and Tang (2013) discuss how hedgers trade frequently and in a contrarian fashion and find that they provide liquidity to speculators. Our paper explicitly relates their trading to output forecasts.
} 
demand shock, all else equal, there is no change in the quantity of expected output, yet our data suggest that hedgers' short positions increase in response to the price increase.

Taken together, the high intensity of hedgers' trading and the sensitivity of their futures positions to prices are difficult to reconcile with the view that hedgers predominantly trade to mitigate cash flow volatility by reducing exposures. Our evidence suggests that, while the overall short positions of hedgers in commodity futures markets do offset commodity price risk, hedgers frequently change their positions over time for reasons unrelated to output fluctuations. Although more elaborate models of hedging may explain a portion of this behavior (Rampini, Sufi, and Viswanathan, 2012), an interesting question for these models is whether they can also simultaneously generate the significant trading we observe in the data.

Overall, the distinction between hedgers and speculators based on whether they have commercial interests or are financial traders is less informative than previously thought for benefitcost analyses of financial regulation. Commercial hedgers appear to engage both in production as well as complex trading activities traditionally viewed as the province of financial firms with specialized trading operations. Both types of traders may be engaged in trades that contribute towards price discovery or perhaps towards notions of reckless speculation. The key challenge lies in distinguishing the motive behind trades.

The paper is organized as follows. Section 1 provides some institutional background and describes the data used in our analysis. Section 2 compares the volatility of hedgers' position changes with the uncertainty in aggregate commodity output. Section 3 examines the responses of hedgers' futures positions to price changes. We conclude in Section 4 with a discussion.

\section{Background and Data on Trader Positions}

Centralized futures markets for agricultural commodities are some of the earliest markets for derivatives in the US, dating back to the mid-1800s and the formation of the Chicago Board of Trade. The futures markets for wheat, corn, soybeans and cotton (the sample of our analysis) continue to thrive, with total open interest averaging \$79 billion dollars in 2010.

Data on positions in these futures markets are collected and published by the Commodity Futures Trading Commission (CFTC). Every day, trader positions in excess of a specified reporting 
threshold, which varies by commodity, are reported to the CFTC by exchange clearing members, futures commission merchants, and foreign brokers. Positions are reported at the contract level (e.g., December 2001 Corn). This data is aggregated by the CFTC into the public Commitment of Traders (COT) reports, and has been published weekly on Tuesdays since 2000 and at a lower but regular frequency before then. Aggregate positions in the COT account for $70 \%-90 \%$ of open interest in any given market.

This report categorizes positions into "Commercial" and "Non-Commercial" positions based on trader classifications self-reported to the CFTC. Traders who exceed the reporting threshold are required to file CFTC Form 40, which requires the trader to disclose information regarding the nature of their business and whether they are using futures to hedge business risk. Based on these forms and conversations with the trader, the CFTC decides how to classify the trader. Since 2009, the CFTC has published a Disaggregated COT (DCOT) report which breaks down positions into those of "Producers/Merchants/Processors/Users," "Swap Dealers," "Managed Money," and "Other Reportable" traders. This data was made available back to 2006 based on existing 2009 classifications cast back to 2006. The CFTC also has published a Supplemental COT (SCOT) report that breaks down positions into those of Commodity Index Investors (CITs), Commercial traders, and Non-Commercial traders. Broadly, Commercial (COT, SCOT) and Producers/Merchants/Processors/Users (DCOT) positions are meant to capture traders who trade futures to hedge their business risk. ${ }^{4}$

Figure 1 plots the aggregated net (long minus short) notional position value (computed using front-month contract prices, downloaded from Bloomberg) for the different DCOT trader categories in the four sample agricultural commodities. It shows that the net positions of Producers/Merchants/Processors/Users consistently form the short side, suggesting that producers' net short positions are much larger than users' net long positions and dominate the positions reported for the group as a whole. Swap dealers and managed money form the long side. Gross positions (open interest) have grown significantly since 2000, as have the net short positions of producers and net long positions of financial traders such as index traders and hedge funds (Cheng, Kirilenko and Xiong, 2013).

\footnotetext{
${ }^{4}$ For a discussion of other trader classes, see Cheng, Kirilenko and Xiong (2013). For a detailed discussion of the explanatory notes of the Disaggregated COT report, see CFTC (2013).
} 
The US Department of Agriculture (USDA) keeps close track of crop production in the US and around the world. Between the $9^{\text {th }}$ and $12^{\text {th }}$ of every month, it publishes the World Agricultural Supply and Demand Estimates (WASDE) report, which tracks estimated production, demand, and stocks for a large number of agricultural and livestock products, including wheat, soybean, corn, and cotton. The latter three are spring-planted crops, while wheat is planted in both the winter and spring. Beginning in May, the USDA will begin forecasting crop production based on trend yields and estimates of intended and planted acreage. ${ }^{5}$ In June, the USDA surveys a large representative sample of farms (in 1999, over 125,000) to gather information on planted acreage, which inform subsequent production estimates. Estimates are revised each following month based on updated surveys about farmers' expected yield, through the beginning and end of fall harvest, after which they are surveyed about actual yields until the end of April of the following calendar year. Estimates from the WASDE report thus represent both the best real-time estimates of aggregate crop production in the US for a coming or in-progress harvest, but also the best historical estimates of total crop production for previous harvests as well. ${ }^{6}$

\section{Output Uncertainty and Hedging Position}

A hedging strategy is often referred to buying or selling of securities intended to offset price fluctuations of existing positions. As a farmer is naturally exposed to price fluctuations of crops in the field, a hedging strategy entails shorting commodity futures contracts to offset any price drop at the harvest time. If there is no output uncertainty, a fixed short position in commodity futures with a size equal to the output would perfectly hedge the price uncertainty faced by the farmer. In the presence of output uncertainty, the optimal hedging strategy is more subtle. Rolfo (1980) argues that output uncertainty leads producers to under-hedge because output is negatively correlated with price. Indeed, by studying price and output uncertainty faced by Cocoa producers in several countries, Rolfo shows that this insight helps explain the widely observed under-hedging by farmers. Hirshleifer (1991) derives a theoretical model to systematically examine the optimal hedging strategy with both output and price uncertainty. It is intuitive that the optimal hedging position fluctuates with the expected output.

\footnotetext{
${ }^{5}$ For wheat, estimates of winter wheat are posted in May, with spring wheat added in July.

${ }^{6}$ For a detailed discussion, see USDA (1999).
} 
We first compare the volatility of positions with the uncertainty in the output. We measure the output uncertainty in two ways, one through the year-to-year fluctuations in output and the other through the fluctuations in the monthly output forecasts provided by the USDA in the WASDE reports.

The aggregate output of a commodity, say wheat, is determined by the acres planted at the beginning of the season and the yield per acre. As the planting area is determined by people, the output uncertainty faced by farmers is mostly from the yield. Figure 2 plots both aggregate output and yield from 1960 to 2012 for wheat, corn, soybeans and cotton. Indeed, the yield of each commodity is either the same or less volatile than the aggregate output, indicating that part of the annual output fluctuations is due to changes in planting acreage.

Figure 3 plots the short positions of Producers/Merchants/Processors/Users from the DCOT as well as Commercial positions from the COT in commodity futures (in output equivalent units) in each of these four commodities together with the aggregate annual output. ${ }^{7}$ The plot suggests that both groups' position changes are much more volatile than the annual output changes. While the DCOT data consistently show that Producers/Merchants/Processors/Users are net short, the COT data show that Commercials often have near-net zero (sometimes even long) positions, highlighting the co-mingling of swap dealer positions with producer positions that plague the original COT report (Cheng, Kirilenko and Xiong, 2013). For the rest of the analysis, we therefore rely on the DCOT data from 2006 onwards, and refer to Producers/Merchants/Processors/Users as producers given their consistently net short positions.

Table 1 describes means and standard deviations of this data in terms of hedge ratios, defined as the short position of producers in commodity futures divided by expected output. Consistent with Rolfo (1980), hedge ratios are far less than one, although this may be partially attributable to comingling of users' positions with producers' positions. The average hedge ratio was roughly $28 \%$ in wheat, $32 \%$ in soybeans, $17 \%$ in corn, and $57 \%$ in cotton over this period. Notably, hedge ratios

\footnotetext{
${ }^{7}$ To convert the output-equivalent futures position, we use the size of the contract (5000 bushels per contract for wheat, corn, soybeans, and $50000 \mathrm{lbs}$ per contract for cotton) as well as the metric conversions reported at the end of each WASDE report ( 0.027216 bushels per metric ton for wheat and soybeans, 0.025401 bushels per metric ton for corn; cotton output is reported in millions of $480 \mathrm{lb}$. bales).
} 
fluctuated significantly over these years, as the standard deviations of hedge ratios over these years was roughly $30 \%$ of the mean in the four commodities. ${ }^{8}$

Figure 4 formalizes this notion by computing the volatility of annual percentage changes in producers' futures position, output, and yield for each of the commodities over the five years from 2007-2011, from the first year we can compute such changes using DCOT data through the last year in which we have finalized ex post output. ${ }^{9}$ If producers were maintaining fixed hedge ratios, these volatilities should be equal. However, the volatility of producers' futures position ranges from 0.5 to 0.7 across the commodities, while the volatility of the annual yield changes stays in a narrow range around 0.07 .

Next, we examine patterns of monthly futures position changes and expected output changes, by month of the harvest. Although the USDA begins issuing forecasts in May based on trends, the harvest for spring crops begins in August for wheat and cotton, and September for corn and soybeans. ${ }^{10}$ As discussed in the previous section, each month's report contains more information about aggregate supply for the year than the last. These forecasts tend to be very informative of the coming year's crops. Figure 5 plots the root mean-squared error (RMSE) of the forecast for twenty years by month from harvest, scaled by the unconditional average of the actual harvest for each commodity. The plot shows that the uncertainty declines monotonically as the harvest season comes closer, as these forecasts converge to the actual harvest. Even in the noisiest first forecast, the average RMSE is between 6 and 13 percent of the harvest.

Figure 6 plots the volatility of percentage changes in producers' futures position together with the volatility of percentage changes in the monthly forecast, again by month from harvest. Two salient observations are common across the commodities. First, the volatility of the producers' futures position changes is several times larger than the volatility of the forecast changes. Second,

\footnotetext{
${ }^{8}$ To compute average hedge ratios across harvests, we first average hedge ratios across 52 weeks within each year, then compute averages and standard deviations of these averages over the harvests.

${ }^{9}$ The figure computes the volatility of annual futures position changes by first computing the average 52-week percent change in futures position across each of the 52 weeks within each year, and then computing the volatility of this average across harvest years. Flipping the order of operations and computing the 52 separate volatilities of 52-week futures changes (one for each week) and then averaging these volatilities yields even more striking results.

${ }^{10}$ Beginning-of-harvest dates can vary by region in the US (USDA, 2010), but these months are the standardized months used by the USDA in their WASDE reports to determine the so-called marketing year.
} 
the volatility of the producers' futures position changes is large throughout the year. The volatility of futures position changes does appear to increase during the planting season (the two months furthest from the harvest, just prior to the first issuance of forecasts for the next harvest, represented by the right-most two points on those graphs), as uncertainty rises presumably with the next planting. Nonetheless, it is high before then, even as output uncertainty is declining.

Figure 7 re-phrases these results again in hedge ratios. The left-hand panel shows that the average hedge ratio across harvests is remarkably stable throughout the harvest year. On the other hand, the right-hand panel shows that there can be large percentage changes in hedge ratios from month to month, as the volatility of these percentage changes across harvests is quite high between 10 and $50 \%$.

In summary, producers' futures positions in the four commodities are several times more volatile than the output uncertainty. However, the co-mingling of producer positions with user positions can pose difficulties for interpreting the relative volatility of position changes and forecast changes. This leads to our next question: what cause hedgers to trade?

\section{Price Changes and Hedging Position}

We next focus on analyzing the correlation between producers' futures position changes and price changes. Figure 8 plots the producers' short position in each of the four commodity futures together with the futures price from January 2006 to December 2012. There is a salient pattern--producers' short positions move in sync with the price. That is, as the price rises, producers increase their short position, while as the price falls, they reduce their short position. Indeed, in contrast to the annual volatility of output changes, the volatility of price changes is on the same order of magnitude as the volatility of position changes, as shown in Figure 2.

Table 2 provides results from a regression of monthly percentage changes in producers' short positions on the 12-month and 1-month percentage changes in output forecasts, and the monthly futures price percentage change. We include a turn-of-harvest effect to control for how output forecasts roll over to the next harvest in May, and fully interact this effect with the main effects of interest. We use the Newey-West (1987) construction of the covariance matrix in computing our standard errors to allow for serial correlation. Coefficients are reported in standardized units of standard deviations of percentage changes in positions per one-standard deviation of the right-hand 
side variable.

From the table, we observe that, first, there is hardly any consistent correlation between the monthly change of producers' short position and the 12-month or 1-month change in forecasted output. Second, the monthly position change is positively and significantly correlated with the monthly futures price change across all commodities. Third, the bulk of the variation in position changes is explained by price changes, as adding the price change term to the forecast output terms increases the R-squared for each commodity significantly (nine-fold for wheat, three-fold for corn, twenty-fold for soybeans, and ten-fold for cotton).

Can we explain the positive correlation between producers' change in short positions and price changes based on a pure hedging strategy? It is difficult to reconcile such trading behavior purely based on hedging strategies of risk-averse producers seeking to hedge price and output uncertainty. To fix intuition, consider a representative producer who faces uncertainty in both price and output. Consider an increase in the price, which may arise due to a negative aggregate supply shock or positive aggregate demand shock. In the former case, all else equal, less output needs to be hedged, yet our data suggests hedgers increase their short positions in response to a higher price. In the latter case, all else equal, there is no change in the quantity of expected output, yet our data suggest that producers' short positions increase with the price increase.

Certain aspects of different hedging models may explain away a portion of this behavior. Negative aggregate supply shocks may put producers closer to financial distress (despite higher prices) so that they need to actively increase their hedge ratio more than that implied by the natural passive increase following the negative quantity shock, as might be suggested by models of hedging such as Smith and Stulz (1985) and Froot, Scharfstein and Stein (1993). Whether this explains the average relationship between price and hedging could be tested in principle by examining whether the price reaction of trading is related to the supply or demand component of price movements, through a careful instrumental variables analysis. Notably, however, Rampini, Sufi and Viswanathan (2012) provide evidence that airline fuel hedging decreases, rather than increases, with financial distress, as hedging requires costly collateral.

This costly collateral mechanism may induce a positive correlation between position changes and prices. For example, producers may increase hedges in response to positive demand shocks that 
raise the price, and thus their net worth. An interesting question for these models is whether they can simultaneously generate the high degree of trading that we observe.

\section{Conclusion and Discussion}

Overall, it is problematic to categorically classify trading by hedgers as hedging and trading by speculators as speculation. Although hedgers tend to take short positions that hedge risk in their commercial business, on the margin, they engage in significant non-output related trading.

One possibility is that hedgers take a view on prices just as speculators do. As noted in Stulz (1996), commercial hedgers may attempt to exploit informational advantages by trading against speculators. For example, agricultural firms may have better knowledge of local physical market conditions across the country, as the opacity of physical markets may induce significant informational frictions. However, it is well known that information asymmetry alone prevents, rather than leads to, trading, as in the No-Trade Theorem of Milgrom and Stockey (1982). Odean (1998) and Scheinkman and Xiong (2013) show that overconfidence or a belief by each trader of an informational advantage over others helps generate excessive trading between groups of traders. In other words, heterogeneous beliefs induced by overconfidence regarding informational advantage leads to excessive trading. Consistent with this notion of speculative trading, another possibility is that by hedging away some of their risk, hedgers are able to speculate more heavily based on their disagreements against speculators regarding future price movements, as in Simsek (2013). ${ }^{11}$ Finally, participants in futures markets are not producers themselves, but are market-makers who trade in futures markets to hedge forward contracts written with the ultimate commodity producers such as farmers, although our analysis would imply these producers are themselves speculating on the price.

Any of the above possibilities raises complex questions, as market-making, speculation based on heterogeneous beliefs, and active trading based on informational advantages are at odds with the canonical notion of hedging behavior. Anecdotal evidence suggests that commercial hedgers speculate on prices using their position both in spot and futures markets. Pleven (2012) relates stories of farmers speculating on rising corn prices using a combination of storage and options

\footnotetext{
${ }^{11}$ The presence of heterogeneous beliefs raises challenges to welfare analysis of futures market trading. See Brunnermeier, Simsek, and Xiong (2012) and Gilboa, Samuelson, and Schmeidler (2012) for recently proposed welfare criterions to analyze welfare in economic models with heterogeneous beliefs.
} 
contracts. Agricultural firms such as Cargill exploit complex trading strategies that profit from the spread between futures and spot prices, and may tilt their exposure based on information about coming shortages or oversupply in certain areas (Davis, 2009). Archer-Daniels-Midland Company (ADM), a large grain processor, notes in its 2012 annual report that it "uses exchange-traded futures and exchange-traded and OTC options contracts as components of merchandising strategies designed to enhance margins" (Archer-Daniels-Midland Company, 2012). Although at odds with the canonical notion of hedging behavior, such trading may contribute towards price discovery if it is based on genuine informational advantages, or may lead to excessive price volatility if it is induced by overconfidence. Further research on this issue is required.

Our analysis offers implications for benefit-cost analysis of financial regulation in two ways. First, from a conceptual point of view, our finding suggests the need to expand the scope of the benefit-cost analysis from the usual emphasis on costs brought by any reckless speculation of financial speculators to cover potential reckless speculation by any market participants, including hedgers with established commercial interests. Second, our finding cautions against overweighting the identity of the trader as a factor in classifying trades, and instead emphasizes the motive of the trade, which may be difficult to ascertain. This caution echoes the concern raised by Cochrane (2013) and Duffie (2013) that policy distinctions based on trading motives may be more challenging to construct than ever. 


\section{References}

Archer-Daniel-Midlands Company (2013), Annual Report Pursuant to Section 13 or 15(d) of the Securities Exchange Act of 1934 (Form 10-K), Available online: http://edgar.sec.gov/Archives/edgar/data/7084/000000708412000034/adm10kfy12.htm [Last Accessed: January 2014].

Brunnermeier, Markus, Alp Simsek, and Wei Xiong (2012), A welfare criterion for models with distorted beliefs, working paper, Princeton University.

Cheng, Ing-Haw and Wei Xiong (2013), The financialization of commodity markets, Annual Review of Financial Economics, forthcoming.

Cheng, Ing-Haw, Andrei Kirilenko and Wei Xiong (2013), Convective risk flows in commodity futures markets, Working paper, Dartmouth College.

Cochrane, John (2013), Cost-benefit analysis as a framework for financial regulation, Working paper, University of Chicago.

Commodities Futures Trading Commission (2013), Disaggregated Explanatory Notes, Available online:

http://www.cftc.gov/MarketReports/CommitmentsofTraders/DisaggregatedExplanatoryNotes/index. htm [Last accessed: October 2013].

Davis, Ann (2009), Cargill's Inside View Helps it Buck Downturn, The Wall Street Journal, January 14, Available online: http://online.wsj.com/news/articles/SB123189501407679581 [Last accessed: January 2014].

Duffie, Darrell (2013), Challenges to a Policy Treatment of Speculative Trading Motivated by Differences in Beliefs, Working paper, Stanford University.

Froot, Kenneth, David Scharfstein, and Jeremy Stein (1993), Risk management: Coordinating corporate investment and financing policies, Journal of Finance 48, 1629-1658.

Gilboa, Itzhak, Larry Samuelson, and David Schmeidler (2012), No-betting Pareto dominance, working paper, Yale University.

Hirshleifer, David (1991), Seasonal patterns of futures hedging and the resolution of output uncertainty, Journal of Economic Theory 53, 304-327.

Kang, Wenjin, K. G. Rouwenhorst and Ke Tang (2013), Who provides liquidity to commodity futures markets?, Working paper, National University of Singapore.

Keynes, John Maynard (1923), Some aspects of commodity markets, Manchester Guardian Commercial, European Reconstruction Series, Section 13, 784-786.

Milgrom, Paul and Nancy Stokey (1982), Information, trade and common knowledge, Journal of Economic Theory 26, 17-27. 
Newey, W.K., and K.D. West (1987), A Simple, Positive Semi-Definite, Heteroskedasticity and Autocorrelation Consistent Covariance Matrix, Econometrica, 55(3), 703-708.

Odean, Terrance (1998), Volume, volatility, price, and profit when all traders are above average, Journal of Finance 53, 1887-1934.

Pleven, Liam (2012), Behind Corn's Squeeze Play: Farmers, The Wall Street Journal, February 28, Available online:

http://online.wsj.com/news/articles/SB10001424052970204778604577243491711608130 [Last accessed: January 2014].

Posner, Eric and Eric Weyl (2013), Benefit-cost analysis for financial regulation, American Economic Review 103 (3), 393-397.

Rampini, Adriano, Amir Sufi, and S. Viswanathan (2013), Dynamic risk management, Journal of Financial Economics, forthcoming.

Rolfo, Jacques (1980), Optimal hedging under price and quantity uncertainty: the case of a cocoa producer, Journal of Political Economy 88, 100-116.

Scheinkman, Jose and Wei Xiong (2003), Overconfidence and Speculative Bubbles, Journal of Political Economy 111(6), 1183-1219.

Simsek, Alp (2013), Speculation and risk sharing with new financial assets, Quarterly Journal of Economics 128, 1365-1396.

Smith, Clifford and Rene Stulz (1985), The determinants of firms' hedging policies, Journal of Financial and Quantitative Analysis 20, 391-405.

Stulz, Rene (1996), Rethinking Risk Management, Journal of Applied Corporate Finance 9, 8-24.

United States Department of Agriculture (1999), Understanding USDA Crop Forecasts, USDA Publication 1554.

United States Department of Agriculture (2010), Field Crops: Usual Planting and Harvesting Dates, Agricultural Handbook Number 628. 
Figure 1: Trader Positions in Commodity Futures Markets

This figure plots the notional value of net positions (the net position times the front-month contract price) aggregated over wheat, corn, soybeans, and cotton for trader categories defined in the DCOT report.

Aggregate Notional Value of Net Positions

Wheat, Corn, Soybeans, Cotton from DCOT

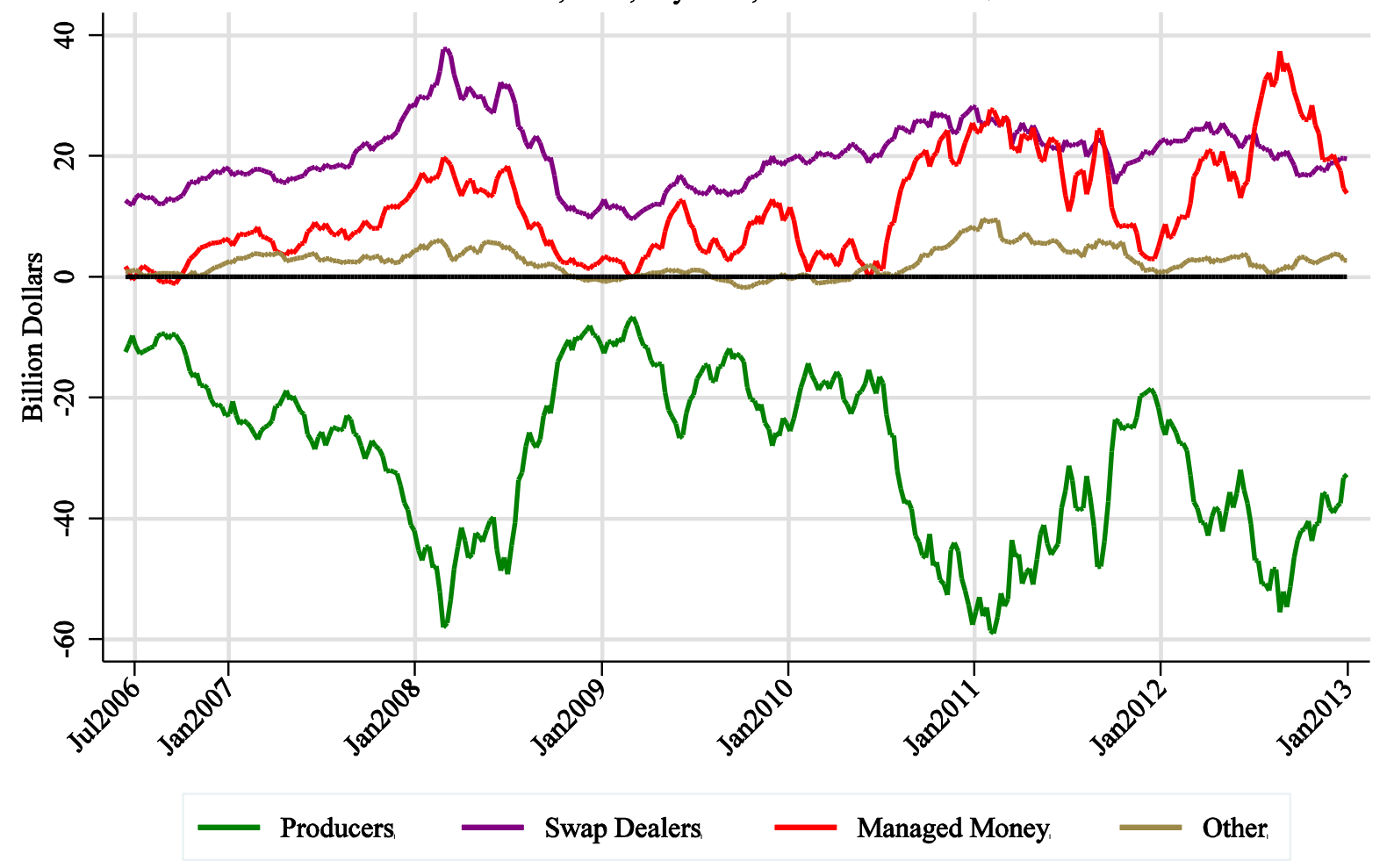




\section{Figure 2: Commodity Production and Yields}

This figure plots US production quantities and yields for wheat, corn, soybeans, and cotton as reported in the WASDE reports.

\section{US Production and Yields}
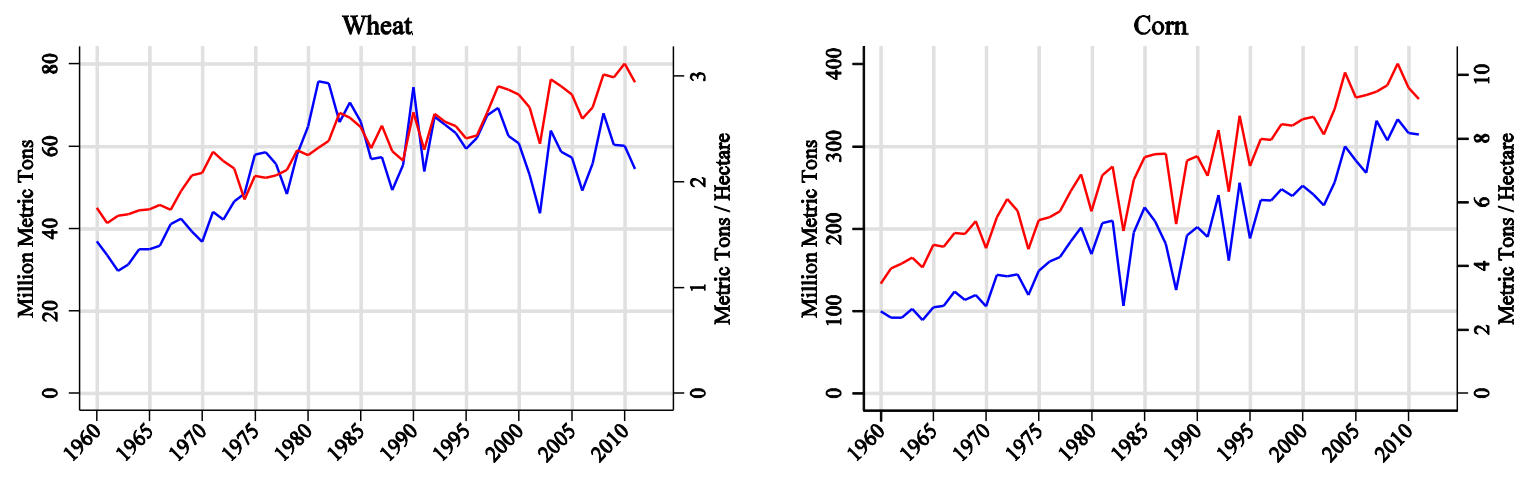

- Production — Yield
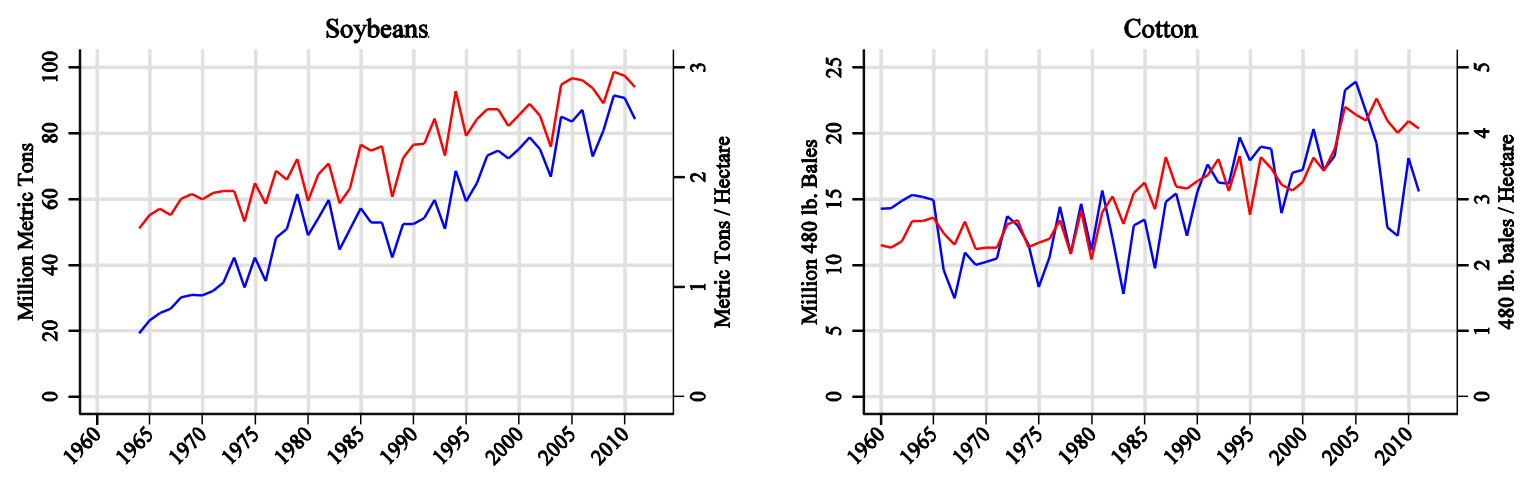

- Production $\longrightarrow$ Yield 


\section{Figure 3: Commodity Output and Hedgers' Futures Positions}

This figure plots the annual realized harvest output reported in the WASDE reports along with weekly positions of futures contracts in output-equivalent units from the COT and DCOT reports.
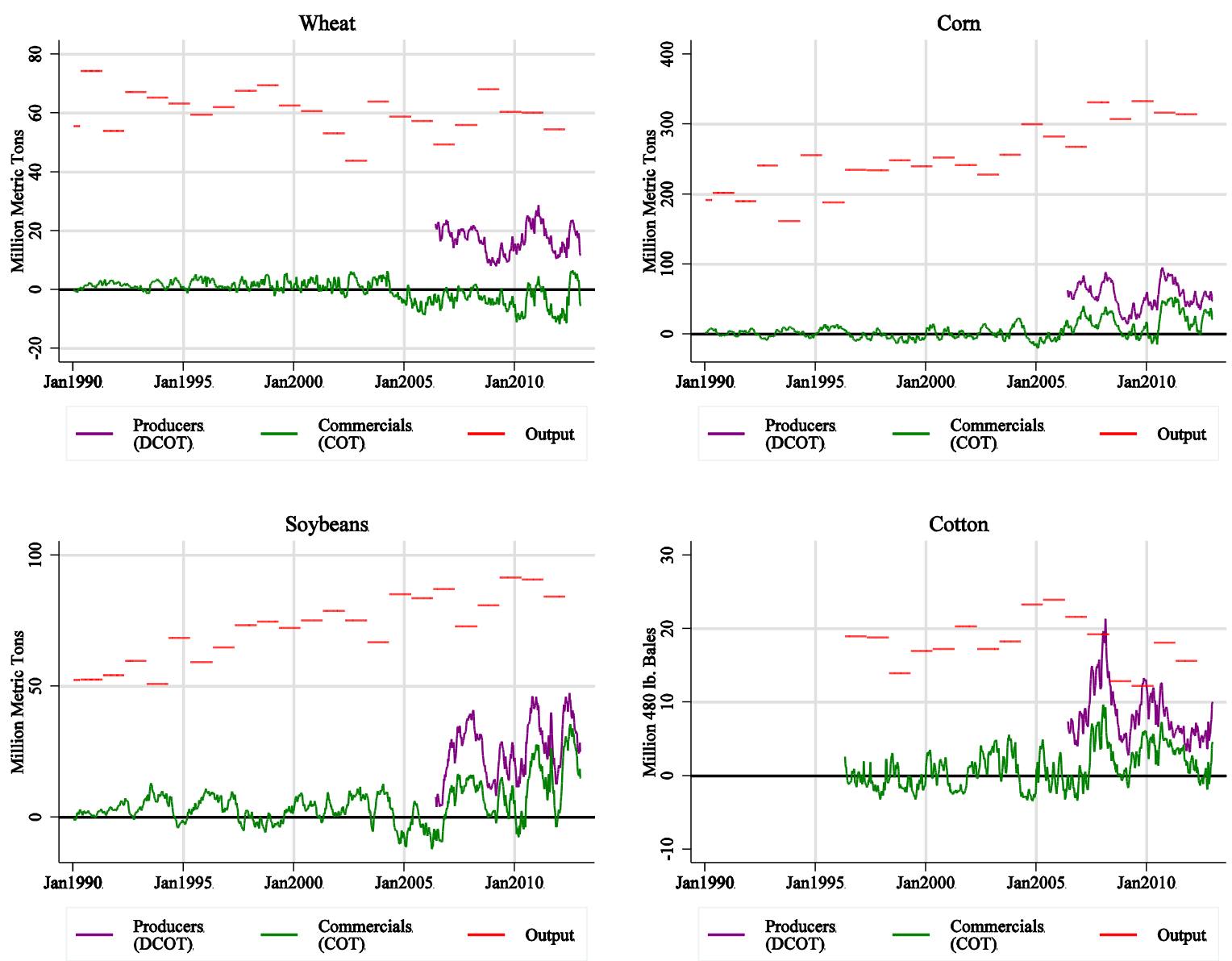
This figure plots the cross-harvest volatility of annual percentage changes in futures positions, realized output, and realized yield.

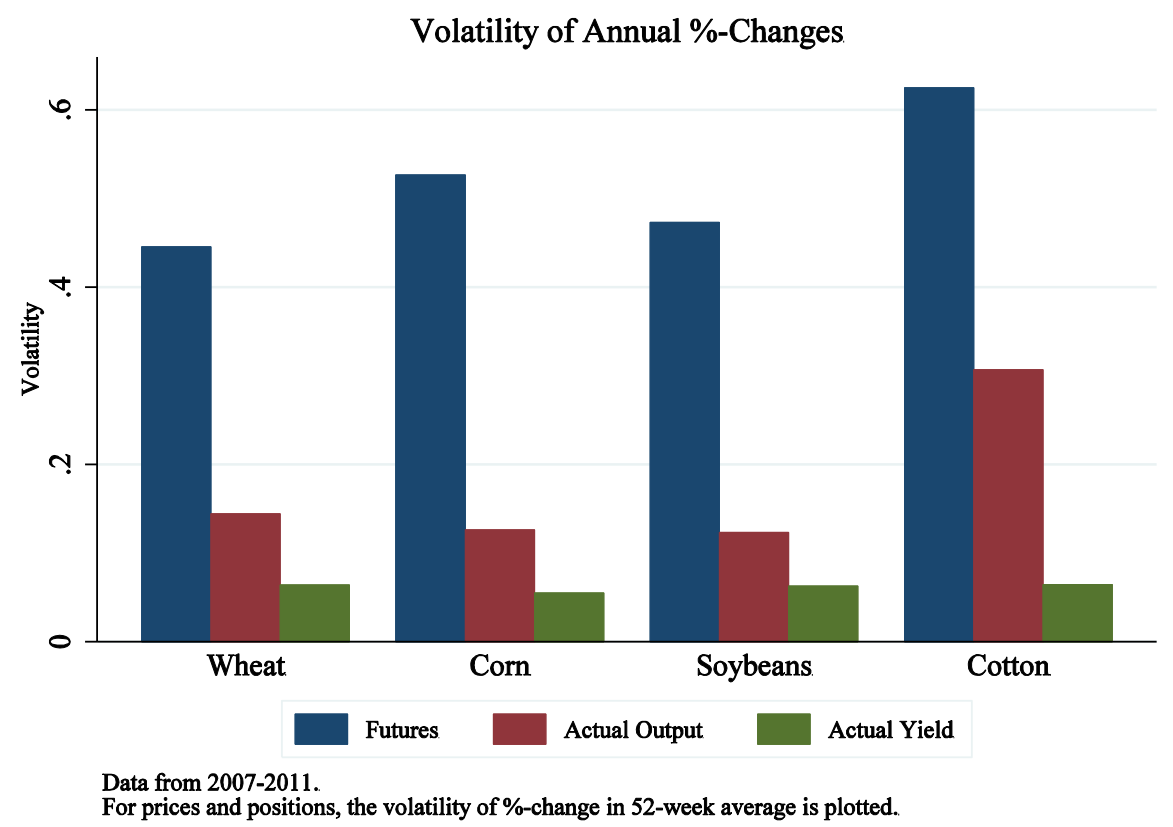

Figure 5: Uncertainty in Output Forecasts

This figure plots the root mean squared error of USDA output forecasts for each commodity by month from the harvest, scaled by the unconditional average harvest size.

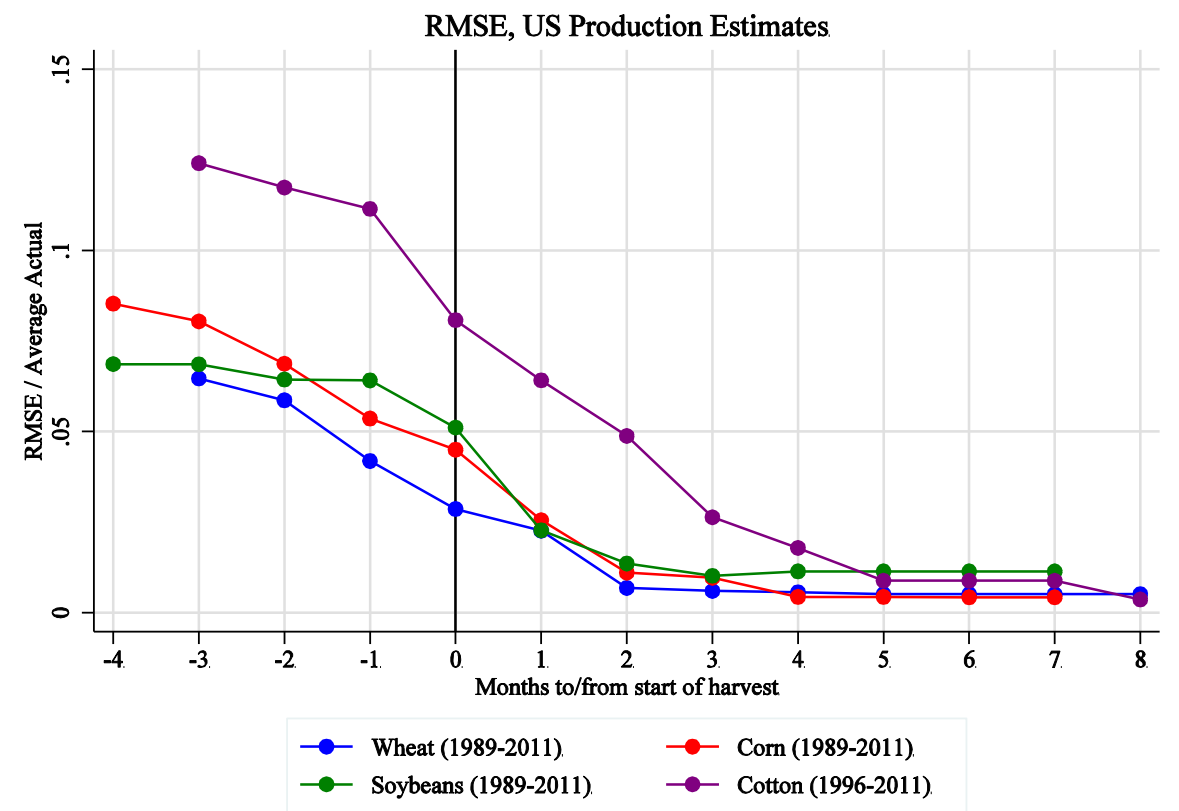




\section{Figure 6: Volatility of Hedgers' Position and Output Forecast}

This figure plots the cross-harvest volatility of monthly percentage changes in USDA output forecasts and producer short positions, by harvest month.

Cross-Harvest Volatility of Monthly \%-Changes
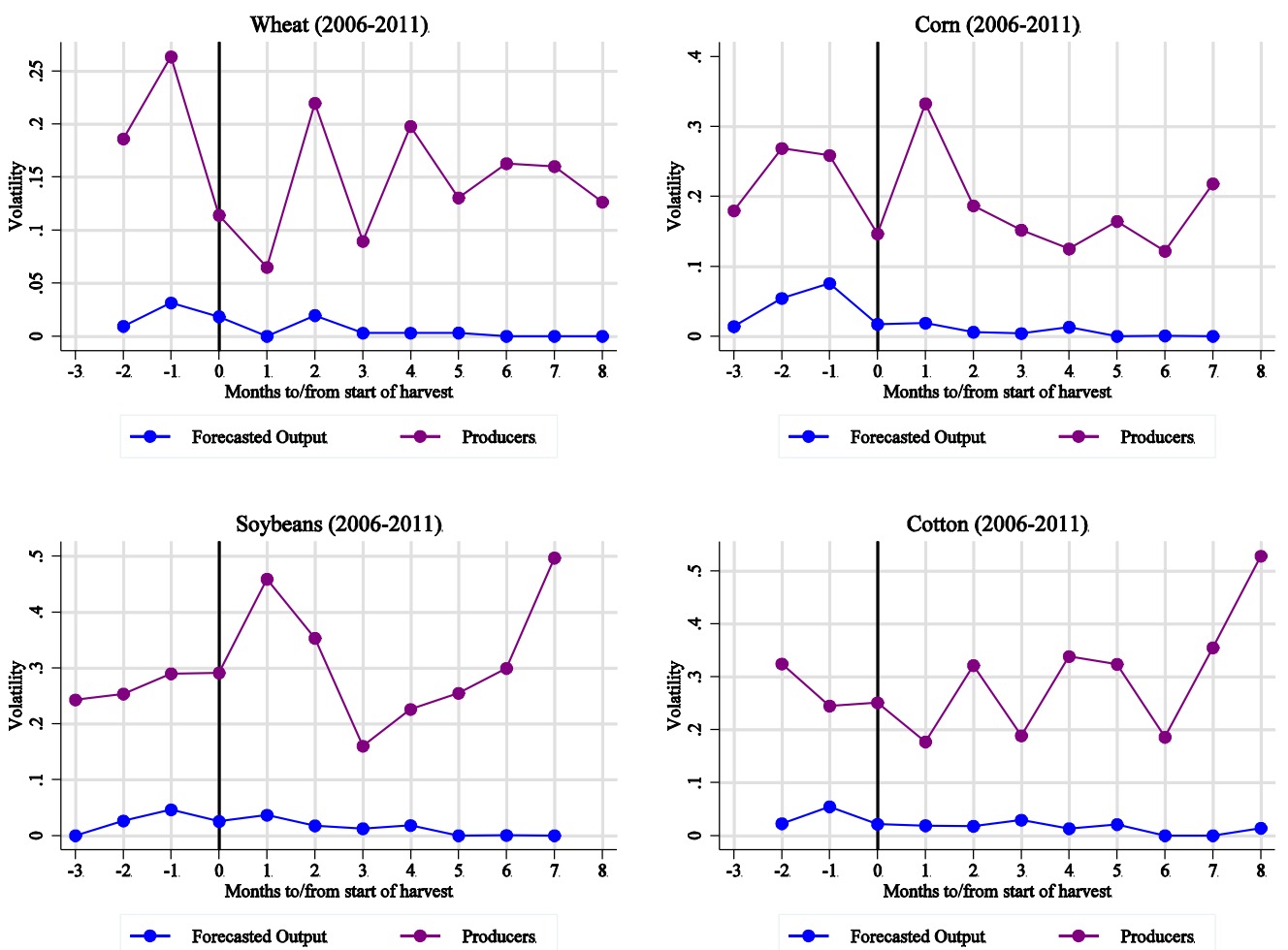

Figure 7: Hedge Ratios

This figure plots the average hedge ratio and cross-harvest volatility of monthly percentage changes in the hedge ratio, by harvest month.

Hedge Ratios
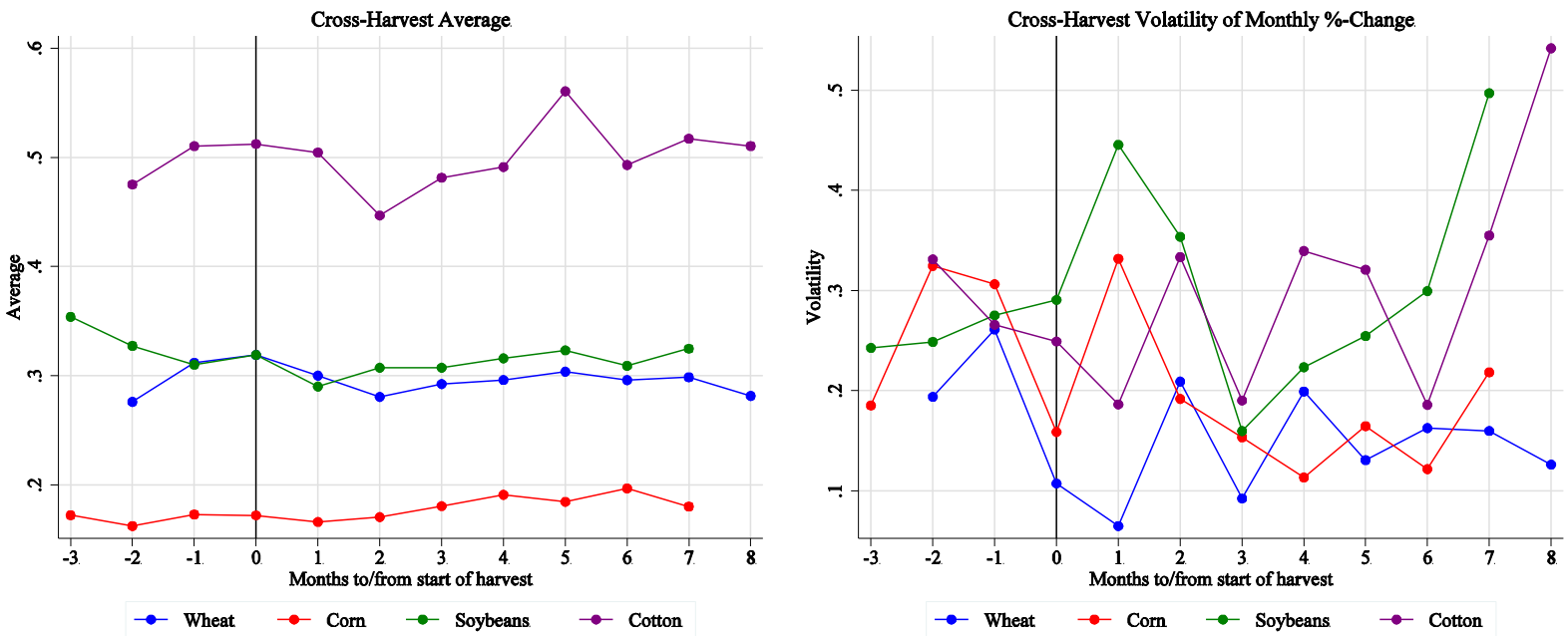


\section{Figure 8: Hedgers' Position and Commodity Futures Price}

This figure plots weekly producer futures positions as well as the front-month futures contract price.
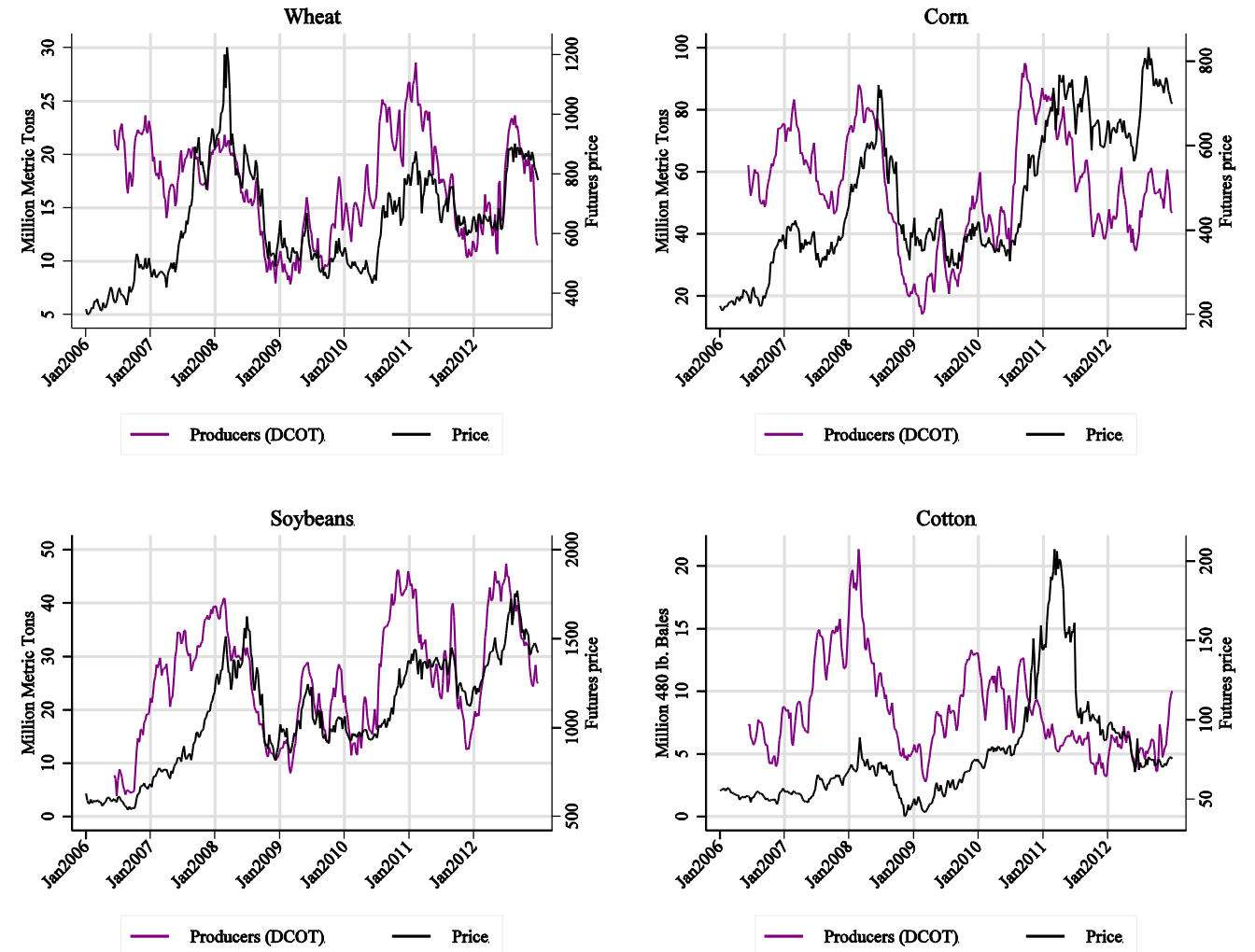

Table 1: Hedge Ratios, 2007-2011 Annual

This table reports summary statistics for hedge ratios from the 2007-2011 harvests.

\begin{tabular}{lccc} 
& Mean & SD & SD / Mean \\
\hline Wheat & 0.28 & 0.08 & 0.29 \\
Corn & 0.17 & 0.04 & 0.27 \\
Soybeans & 0.32 & 0.10 & 0.32 \\
Cotton & 0.57 & 0.19 & 0.34
\end{tabular}




\section{Table 2: Hedgers' Futures Position Changes and Futures Price Changes}

This table reports results from a time-series regression at the monthly frequency of the 1-month percentage change in futures position as the dependent variable on percentage changes in output forecasts and percentage changes in futures positions. We include a turn-of-harvest effect for the month in which output forecasts for the new harvest year are first issued and fully interact this with all other terms; these coefficients are omitted for brevity. Standard errors reported in brackets are computed using the Newey-West (1987) construction of the covariance matrix with three lags. $* / * * / * * *$ denote statistically significant at the $10 \%, 5 \%$, and $1 \%$ levels, respectively.

\begin{tabular}{|c|c|c|c|c|c|c|}
\hline \multirow{2}{*}{$\begin{array}{l}\text { Dependent variable: } \\
1 \text {-month \% change in futures position }\end{array}$} & \multicolumn{3}{|c|}{ Wheat } & \multicolumn{3}{|c|}{ Corn } \\
\hline & (1) & (2) & (3) & (4) & (5) & (6) \\
\hline \multirow[t]{2}{*}{12 -month $\%$ change in output forecast } & 0.014 & & -0.022 & 0.156 & & 0.015 \\
\hline & [0.13] & & {$[-0.29]$} & {$[1.61]$} & & {$[0.20]$} \\
\hline \multirow[t]{2}{*}{1 -month $\%$ change in output forecast } & 0.312 & & 0.262 & -0.502 & & -0.011 \\
\hline & [0.54] & & {$[0.78]$} & {$[-5.23] * * *$} & & {$[-0.06]$} \\
\hline \multirow[t]{2}{*}{ 1-month $\%$ change in futures price } & & 0.530 & 0.529 & & 0.628 & 0.624 \\
\hline & & {$[4.39]^{* * *}$} & {$[4.35]^{* * *}$} & & {$[6.49] * * *$} & {$[4.55]^{* * *}$} \\
\hline \multirow[t]{2}{*}{ Constant } & 0.005 & -0.055 & -0.066 & -0.005 & -0.049 & -0.052 \\
\hline & [0.05] & {$[-0.70]$} & {$[-0.77]$} & {$[-0.04]$} & {$[-0.63]$} & {$[-0.58]$} \\
\hline Fully interacted turn-of-harvest effect & $\mathrm{Y}$ & $\mathrm{Y}$ & $\mathrm{Y}$ & $\mathrm{Y}$ & $\mathrm{Y}$ & $\mathrm{Y}$ \\
\hline $\mathrm{T}$ & 78 & 78 & 78 & 78 & 78 & 78 \\
\hline R-squared & 0.041 & 0.370 & 0.379 & 0.144 & 0.418 & 0.423 \\
\hline \multirow{2}{*}{$\begin{array}{l}\text { Dependent variable: } \\
1 \text {-month \% change in futures position }\end{array}$} & \multicolumn{3}{|c|}{ Soybeans } & \multicolumn{3}{|c|}{ Cotton } \\
\hline & (7) & (8) & (9) & (10) & (11) & (12) \\
\hline \multirow[t]{2}{*}{12 -month $\%$ change in output forecast } & 0.009 & & 0.122 & -0.054 & & -0.243 \\
\hline & [0.08] & & [1.31] & {$[-0.53]$} & & {$[-2.05]^{* *}$} \\
\hline \multirow[t]{2}{*}{ 1-month $\%$ change in output forecast } & 0.205 & & 0.384 & -0.271 & & -0.056 \\
\hline & [1.22] & & {$[3.19] * * *$} & {$[-1.17]$} & & {$[-0.26]$} \\
\hline \multirow[t]{2}{*}{1 -month $\%$ change in futures price } & & 0.632 & 0.701 & & 0.461 & 0.549 \\
\hline & & {$[5.22]^{* * *}$} & {$[5.30]^{* * *}$} & & {$[2.53]^{* *}$} & {$[3.21]^{* * *}$} \\
\hline \multirow[t]{2}{*}{ Constant } & 0.184 & 0.062 & 0.066 & 0.114 & 0.070 & 0.028 \\
\hline & [1.46] & {$[0.70]$} & {$[0.81]$} & [1.19] & {$[0.84]$} & {$[0.33]$} \\
\hline Fully interacted turn-of-harvest effect & $\mathrm{Y}$ & $\mathrm{Y}$ & $\mathrm{Y}$ & $\mathrm{Y}$ & $\mathrm{Y}$ & $\mathrm{Y}$ \\
\hline $\mathrm{T}$ & 78 & 78 & 78 & 78 & 78 & 78 \\
\hline R-squared & 0.023 & 0.412 & 0.491 & 0.019 & 0.185 & 0.241 \\
\hline
\end{tabular}

